\title{
Protective effect of sildenafil on the genotoxicity and cytotoxicity in apolipoprotein E-deficient mice bone marrow cells
}

Franciane P. Bernardes ${ }^{1 \dagger}$, Alan T. Batista ${ }^{1 \dagger}$, Marcella L. Porto ${ }^{2}$, Elisardo C. Vasquez ${ }^{1,3}$, Bianca P. Campagnaro ${ }^{3}$ and Silvana S. Meyrelles ${ }^{1 *}$

\begin{abstract}
Background: The pharmacological inhibitor of phosphodiesterase 5 (PDE5), sildenafil, is a promising candidate for antioxidant therapy that can result in cardiovascular protection. In addition to its known effects on the cardiovascular system, hypercholesterolemia leads to increased oxidative stress and DNA damage in the bone marrow, which is a non-classical target organ of atherosclerosis. In the present study, we evaluate oxidative stress and assess the effect of genomic instability on cell cycle kinetics in atherosclerotic animals and determine if sildenafil reverses these detrimental effects in bone marrow cells.

Methods: Experiments were performed in male wild-type (WT) and apolipoprotein $E$ knockout mice (apoE ${ }^{-/-}$) (9 weeks of age). apoE ${ }^{-1-}$ mice were randomly distributed into the following 2 groups: sildenafil-treated (40 mg/kg/day for 3 weeks, $n=8$ ) and vehicle-treated $(n=8)$, by oral gavage. After treatment, bone marrow cells were isolated to assess the production of superoxide anions and hydrogen peroxide, determine cell cycle kinetics and evaluate the presence of micronucleated cells.

Results: Sildenafil treatment reduced the cytoplasmic levels of superoxide anion ( $95 \%$ decrease, $p<0.05)$ and decreased hydrogen peroxide $(\sim 30 \%$ decrease, $p<0.05)$. Moreover, we observed protective effects on the DNA of bone marrow cells, including normal cell cycling, decreased DNA fragmentation and a diminished frequency of micronucleated cells.

Conclusion: Our data reveal that the excessive production of ROS in atherosclerotic mice overcome the DNA repair pathways in bone marrow cells. The novelty of the present study is that the administration of sildenafil reduced ROS to baseline levels and, consequently, reverted the DNA damage and its outcomes in bone marrow cells.
\end{abstract}

Keywords: Atherosclerosis, ROS, Micronucleus, DNA, Genotoxicity

\section{Background}

Hypercholesterolemia remains one of the most important risk factors for cardiovascular morbidity and mortality [1-4]. High plasma cholesterol levels trigger a cascade of events, including inflammation [5], oxidative stress [6] and cell damage [7,8], particularly in the

\footnotetext{
* Correspondence: meyrelle.vix@terra.com.br

${ }^{\dagger}$ Equal contributors

'Laboratory of Translational Physiology, Health Sciences Center, Federal

University of Espirito Santo, Vitoria, Brazil

Full list of author information is available at the end of the article
}

cardiovascular system [3]. Additionally, we have previously shown that hypercholesterolemia increases oxidative stress in different cell types $[6,7,9,10]$, including bone marrow mononuclear cells [8].

To understand the mechanisms underlying atherosclerosis development and progression and how it impacts cell function, we use apolipoprotein $\mathrm{E}$ deficient $\left(\mathrm{apoE}^{-/-}\right)$mice $[1-3,11]$, which show high levels of plasma cholesterol and develop atherosclerotic lesions that resemble human disease. Emerging evidence suggests the beneficial effects of phosphodiesterase 5 (PDE5) inhibition with sildenafil 
on cardiovascular diseases and other target organs $[6,7$, 10, 12-14]. However, the effects of sildenafil on oxidative DNA damage in bone marrow cells from apoE ${ }^{-/-}$mice have yet to be characterized.

Our study is the first work attempting to characterize the anti-oxidant effect of sildenafil on bone marrow cells as a means of protecting the main source of adult stem cells from damaging reactive oxygen species (ROS). This study has important implications for cardiovascular diseases, including atherosclerosis, a known risk factor for the development of cardiac, renal and vascular morbidities $[6,10]$.

In the present work, we assess oxidative stress and the link between genomic instability and cell cycle kinetics in atherosclerotic animals. Additionally, we evaluate the ability for sildenafil to prevent the damage incurred by ROS in bone marrow cells. To our knowledge, this is the first report demonstrating that chronic sildenafil administration prevents oxidative stress, genomic instability and cell cycle arrest in bone marrow cells in atherosclerotic mice.

\section{Methods}

\section{Animals}

The experiments were performed in 9-week-old male wild-type C57BL/6 (WT, $n=8$ ) and apolipoprotein Edeficient $\left(\mathrm{apoE}^{-/-}\right)$mice. The animals were bred and maintained in the animal care facility at the Laboratory of Translational Physiology at the Federal University of Espirito Santo, Brazil. Mice were housed in individual plastic cages with a controlled temperature $\left(22-23{ }^{\circ} \mathrm{C}\right.$ ) and humidity $(60 \%)$ and were exposed to a 12:12-h lightdark cycle. All mice were fed a standard chow diet and had access to water ad libitum. apoE ${ }^{-/-}$mice were distributed into the following 2 groups: ( $n=8$ per group) sildenafil (Viagra ${ }^{\circ}$, Pfizer Laboratory, São Paulo, Brazil)-treated by oral gavage, $40 \mathrm{mg} / \mathrm{kg} /$ day for 3 weeks (Sil) and vehicle (saline)-treated. All experimental procedures were performed in accordance with the guidelines for the care and handling of laboratory animals as recommended by the National Institutes of Health (NIH), and the study protocols were previously approved by the Institutional Animal Care Committee (CEUA-UFES, Protocol \# 008/2015).

\section{Analysis of plasma cholesterol and triglycerides}

The total serum cholesterol and triglycerides from blood samples were determined using commercial colorimetric assay kits (Bioclin, Belo Horizonte, Brazil).

\section{Isolation of bone marrow cells}

Bone marrow cells were obtained from the femurs and tibias of mice euthanized with a sodium thiopental overdose (100 mg/kg, i.p.). After cleaning all soft tissue, epiphyses were removed to gain access to the marrow cavities. Whole bone marrow was flushed out with DMEM, and the resultant cell suspension was incubated twice with a lysing buffer for $5 \mathrm{~min}$ at $37^{\circ} \mathrm{C}$ to remove erythrocytes. The cell suspension was subsequently centrifuged for $10 \mathrm{~min}$ at $1200 \mathrm{rpm}$. The cells were counted and assessed for viability in Neubauer chamber [15]. The samples were considered viable when $\geq 90 \%$ were found to be alive.

\section{Measurement of intracellular ROS}

ROS analysis was performed by flow cytometry using dihydroethidium (DHE) and dichlorofluorescein diacetate (DCF) to detect intracellular $\cdot \mathrm{O}_{2}^{-}$and $\mathrm{H}_{2} \mathrm{O}_{2}$, respectively, as previously described $[8,16]$. Briefly, DHE $(160 \mathrm{mM})$ and DCF-DA $(20 \mathrm{mM})$ were added to a cell suspension of $10^{6}$ cells and incubated at $37{ }^{\circ} \mathrm{C}$ for $30 \mathrm{~min}$ in the dark. The cells were kept on ice until flow cytometric acquisition (10,000 events; FACSCanto II, Becton Dickinson, San Juan, CA). The data were analyzed using FACSDiva software (Becton Dickinson) and were expressed as median fluorescence intensity (MFI).

\section{Cell cycle analysis}

Cell cycle distribution in bone marrow cells was determined by flow cytometry analysis using propidium iodide (PI), as previously described [15]. Briefly, bone marrow cells were fixed, for $2 \mathrm{~h}$, in cold $70 \%$ ethanol and then incubated, for $30 \mathrm{~min}$, with staining solution $(20 \mathrm{mg} / \mathrm{mL}$ RNAse A, $500 \mathrm{mg} / \mathrm{mL}$ PI, 1 \% Triton X-100). For determination of cell cycle distribution, samples were processed in triplicate (10,000 events; FACSCanto II flow cytometer). The cell cycle profile was determined via data analysis performed with FACSDiva software. The data are expressed as the percentage of cells in each cell cycle phase (sub- $G_{0}$, $\mathrm{G}_{0} / \mathrm{G}_{1}, \mathrm{~S}$ and $\left.\mathrm{G}_{2} / \mathrm{M}\right)$.

\section{Micronucleus analysis}

To evaluate the genotoxic risk of atherosclerosis and the anti-genotoxic activity of sildenafil in mice, the micronucleus test was performed on bone marrow cells. The experiments were performed according to von Ledebur and Schmid [17]. Briefly, bone marrow cells were flushed out from the humerus with foetal bovine serum. After centrifuging (1000 rpm, $10 \mathrm{~min}$ ), cells were resuspended and a drop was smeared on individual glass slides. The samples were then fixed in methanol for $24 \mathrm{~h}$ and subsequently stained with Leishman stain. Slides were analyzed under a light microscope $(\times 1000)$ to detect micronuclei in young red blood cells from each experimental group. The number of micronucleated polychromatic erythrocytes (PCE) was determined using two slides per animal and 1000 PCE per slide. The genotoxicity and antigenotoxicity were determined by comparing the number of micronucleated PCE in each group. In addition, cytotoxicity was evaluated by the ratio of PCE 
to normochromatic erythrocytes (PCE/NCE) in the first 200 cells observed [18].

\section{Statistical analysis}

All data are shown as the mean \pm SEM. The normality of the variables was previously analyzed using the Kolmogorov-Smirnov test. Because the data exhibited a Gaussian distribution, the statistical analysis was performed using the one-way analysis of variance (ANOVA). When the ANOVA showed significant differences, the Tukey's test was performed as a post hoc analysis. The differences between the means were considered significant at $p<0.05$.

\section{Results}

\section{Plasma cholesterol and triglycerides}

Table 1 shows the average values of total plasma cholesterol and triglycerides in WT and $\mathrm{apoE}^{-/-}$mice treated with sildenafil or vehicle. As expected, cholesterol and triglyceride levels in $\mathrm{apoE}^{-/-}$mice were $\sim 5$ - and $\sim 3$-fold higher, respectively, than those in WT mice $(p<0.001)$. Sildenafil treatment did not change the values of these parameters.

\section{Bone marrow cell counting and viability}

Figure 1 summarizes the average number of bone marrow cells counted in WT, apoE ${ }^{-/-}$and Sil treated mice. apoE ${ }^{-/-}$ mice showed a decreased number of cells $(110 \pm 5, p<$ 0.01 ), in contrast with Sil mice, which exhibited an increased number of cells $(173 \pm 3$ cells, $p<0.05)$ compared with WT mice ( $157 \pm 5$ cells). Cell viability (the total number of cells minus the number of dead cells) was $\geq 95 \%$ in all three groups.

\section{ROS levels}

Figure 2 summarizes the MFI values of bone marrow cells $\bullet \mathrm{O}_{2}^{-}$(Fig. 2a) and $\mathrm{H}_{2} \mathrm{O}_{2}$ (Fig. 2b) production, determined by flow cytometry, using DHE and DCF-DA fluorescent dyes, respectively. As expected, apoE ${ }^{-/-}$mice exhibited a markedly augmented (+96\%, $p<0.01)$ production of $\mathrm{O}_{2}^{-}(2218 \pm 360 \mathrm{MFI})$ compared with WT animals $(1128 \pm 28 \mathrm{MFI})$. These increased values were reduced to a level comparable to those found in WT controls upon treatment with sildenafil $(1126 \pm 190$ MFI). The production of $\mathrm{H}_{2} \mathrm{O}_{2}$ was also significantly higher in the apoE ${ }^{-1-}$ group $(30 \%, p<0.01)$ compared with WT animals $(2181 \pm 107$ MFI) but was reduced upon sildenafil treatment to a level comparable with that found in WT mice (2107 $\pm 80 \mathrm{MFI})$.

Table 1 Plasma cholesterol and triglycerides

\begin{tabular}{llll}
\hline Parameter & WT & apoE $^{-/-}$ & Sildenafil \\
\hline Total cholesterol (mg/dL) & $113 \pm 7$ & $542 \pm 10^{*}$ & $554 \pm 15^{*}$ \\
Triglycerides $(\mathrm{mg} / \mathrm{dL})$ & $66 \pm 4$ & $192 \pm 14^{*}$ & $184 \pm 16^{*}$ \\
\hline
\end{tabular}

The values are the means \pm SEM

${ }^{*} p<0.05$ vs. WT group (one-way ANOVA and Tukey's test)

\section{Evaluation of cell cycle distribution}

Considering that augmented ROS is known to cause damage to DNA, we evaluated cell cycle distribution by PI staining and flow cytometric analysis. We determined the percentage of cells with fragmented (sub-G0; $x<2 \mathrm{n}$ ), interphasic $(\mathrm{G0} / \mathrm{G} 1 ; \mathrm{x}=2 \mathrm{n})$, duplicating $(\mathrm{S} ; 2 \mathrm{n}<\mathrm{x}>4 \mathrm{n})$ and duplicated $(G 2 / M ; x=4 n)$ DNA. Figure 3 shows the percentage of cells in different phases of the cell cycle, including sub- $G_{0}$ (Fig. 3a), $G_{0} / G_{1}$ (Fig. 3b), $S$ (Fig. 3c) and $G_{2} / M$ (Fig. 3d). The percentage of bone marrow cells in sub- $G_{0}$ and $G_{0} / G_{1}$ phases was significantly augmented in apoE ${ }^{-/-}$mice compared with WT animals; these parameters returned to control group values in in $\mathrm{apoE}^{-/-}$mice chronically administered with sildenafil (Sub-G - WT: $1.6 \pm 0.10 \%$ vs. apoE ${ }^{-/-}: 2.2 \pm 0.12 \%$ vs. Sil: $1.3 \pm 0.1 \%$, Fig. $3 \mathrm{a}$; and $\mathrm{G}_{0} / \mathrm{G}_{1}-\mathrm{WT}$ : $68 \pm 0.5 \%$ vs. apoE ${ }^{-/-}: 75 \pm 0.7 \%$ vs. Sil: $67 \pm 1.6 \%$, Fig. $\left.3 \mathrm{~b}\right)$. The percentage of bone marrow cells in $S$ and $G_{2} / M$ phases was significantly diminished in apoE ${ }^{-1-}$ mice compared with WT animals; chronic administration with sildenafil returned these parameters to WT levels (S - WT:24 \pm $2 \%$ vs. apoE ${ }^{-/-}: 17 \pm 2 \%$ vs. Sil: $25 \pm 2 \%$, Fig. 3c; and $\mathrm{G}_{2} / \mathrm{M}-\mathrm{WT}: 7 \pm 0.2 \%$ vs. apoE ${ }^{-/-}: 5.5 \pm 0.2 \%$ vs. Sil: 8 $\pm 0.3 \%$, Fig. 3d).

\section{Micronucleus test}

In the present study, the micronucleus test was performed on bone marrow samples to investigate the protective effects of sildenafil on the DNA of $\mathrm{apoE}^{-/-}$mice. Figure 4a shows typical images of PCE, NCE and micronucleated PCE (MNPCE) in bone marrow. A significant increase in micronuclei incidence was observed in apoE ${ }^{-1-}$ mice $(6.4 \pm 0.35 \mathrm{MNPCE})$ compared with WT mice ( $3.5 \pm 0.27 \mathrm{MNPCE})$, and sildenafil treatment (5.0 \pm 0.41 MNPCE) was able to reduce the frequency of micronucleated cells (Fig. 4b). In addition, the ratio of PCE/NCE reveals that atherosclerosis, per se, yields a cytotoxic effect compared with WT mice (WT: $0.52 \pm 0.01$ vs. apoE $\left.{ }^{-/}: 0.28 \pm 0.03\right)$. Additionally, sildenafil treatment protected bone marrow cells of apoE ${ }^{-/-}$mice from the cytotoxic effect of hypercholesterolemia $(0.42 \pm 0.02)$.

\section{Discussion}

This study shows, for the first time, that chronic inhibition of PDE5 with sildenafil restores cell cycle kinetics/ progression and prevents genomic instability by decreasing ROS production in bone marrow cells of apoE $\mathrm{E}^{-/-}$ mice. We have previously demonstrated the link between increased ROS production and DNA damage in bone marrow cells from apoE ${ }^{-/-}$mice [8]. We have also demonstrated that sildenafil treatment was able to reduce DNA damage in blood, renal and liver cells [7, 12]. However, there is no evidence of sildenafil's antioxidative effect on bone marrow cells and, consequently, on DNA 


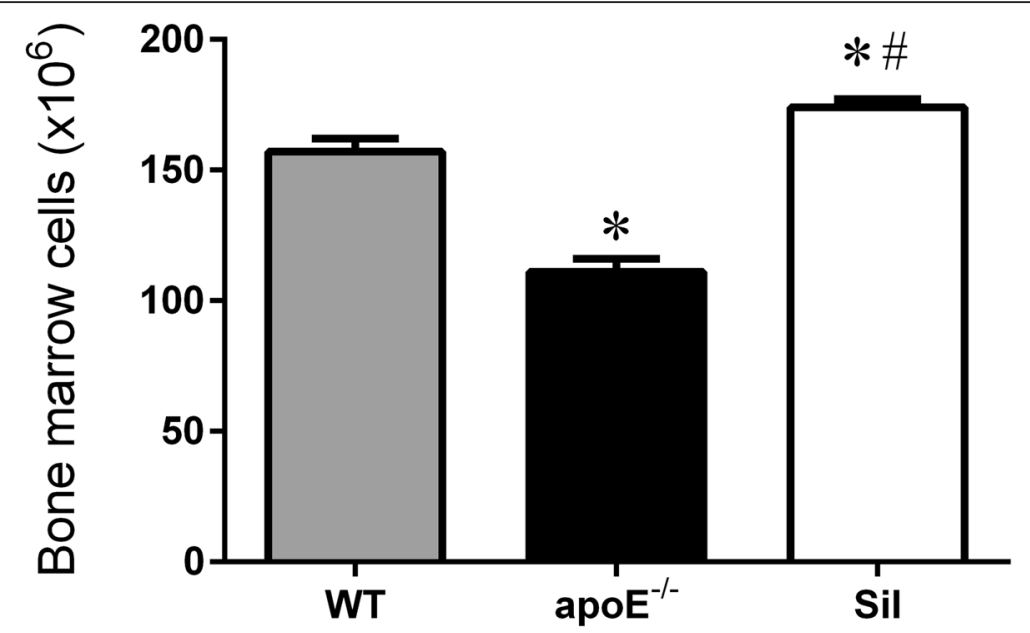

Fig. 1 Number of bone marrow cells counted in $\mathrm{WT}$, apoE $\mathrm{E}^{-/-}$and Sil mice using a Neubauer chamber. The values are the means \pm SEM. ${ }^{*} p<0.05$ vs. WT group; ${ }^{p} p<0.05$ vs. apoE ${ }^{-/-}$group (one-way ANOVA)

damage. To explore this phenomenon, we evaluated the effects of sildenafil as an antioxidant, anti-genotoxic and, consequently, anti-mutagenic drug in the bone marrow cells of apoE ${ }^{-/-}$mice.

Atherosclerotic mice showed higher plasma cholesterol and triglyceride levels than WT mice, corroborating recent findings $[6,7,10]$. The chronic administration of sildenafil did not change the plasma lipid profile in atherosclerotic animals, which is in agreement to previous results $[6,7,10]$.

Oxidative stress has been implicated as a causative factor in cardiovascular diseases [18]. During atherosclerotic plaque development, cells accumulate high levels of ROS, which play an important role in disease initiation and progression [1-3]. Excess of ROS can trigger toxic effects by damaging biomolecules, which leads to cell death $[7,8,12,16]$. In the present study, superoxide anion and hydrogen peroxide levels were augmented in bone marrow cells from apoE ${ }^{-/-}$mice. These findings are in agreement with Tonini et al. [8], likely due to the hyperactivation of ROS-producing enzymes and the decreased activity of ROS-scavenger enzymes [19-23]. In addition, we demonstrated, for the first time, that chronic treatment with sildenafil was able to restore ROS production to a baseline level in bone marrow cells from apoE ${ }^{-/-}$mice. It is known that sildenafil regulates $\mathrm{NO} / \mathrm{cGMP}$ signaling, which has been implicated in the pathogenesis of atherosclerosis $[6,10]$. Taken together, these data show that sildenafil reduces ROS production, without modifying the lipid profile of $\mathrm{apoE}^{-/-}$mice.

ROS are well-known genotoxins that have been associated with DNA damage in cardiovascular diseases [8, 9, 12, 15]. It has been postulated that atherosclerosis leads to oxidative stress and could, indirectly, cause genomic instability, as
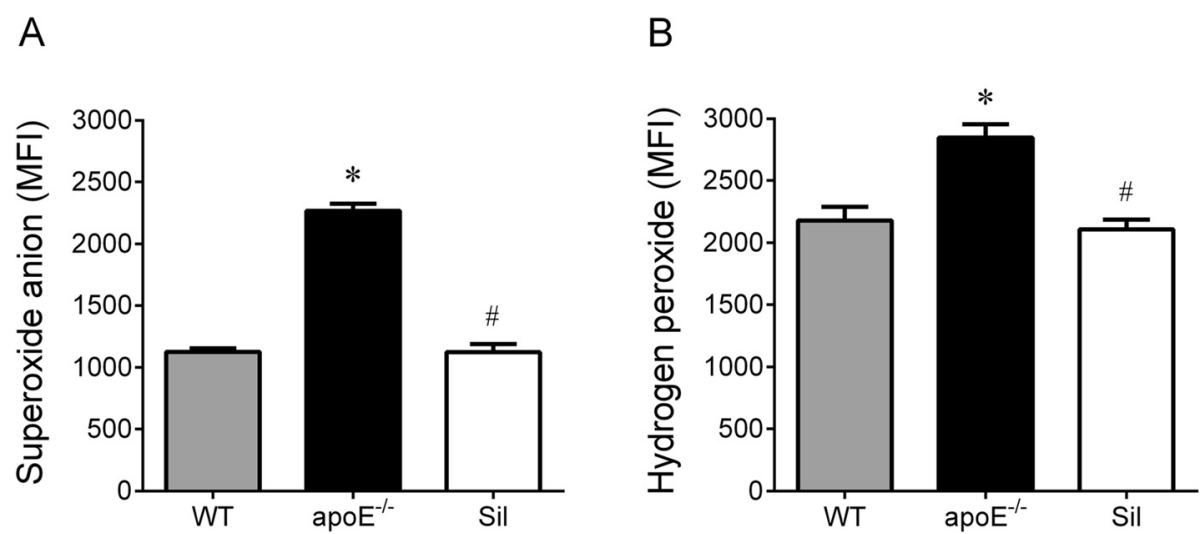

Fig. 2 Levels of ROS in bone marrow cells using dihydroethidium (DHE) and dichlorofluorescein diacetate (DCF) to detect intracellular superoxide anion (a) and hydrogen peroxide (b), respectively, in WT, apoE ${ }^{-/-}$and Sil mice. The values are the means \pm SEM. ${ }^{*} p<0.05$ vs. WT group; ${ }^{\#} p<0.05$ vs. apoE ${ }^{-/-}$group (one-way ANOVA) 

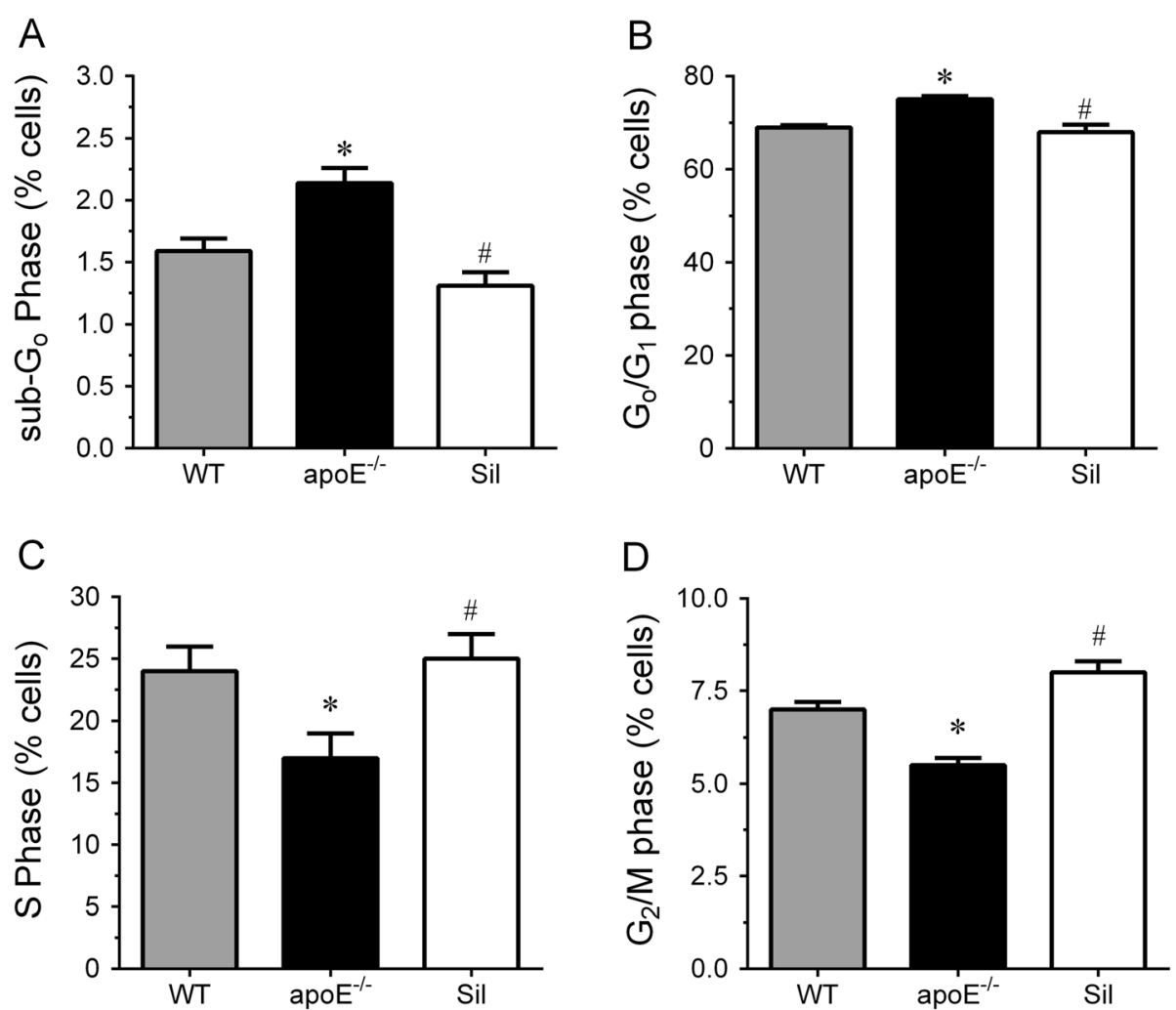

Fig. 3 Effects of sildenafil treatment on cell cycle distribution in bone marrow cells from WT, apoE ${ }^{-/-}$and Sil mice. The cell cycle distribution was monitored via PI staining and flow cytometric analysis. Statistical analysis of the percentage of cells in sub-G-phase $(\mathbf{a}), G_{0} / G_{1}-$ phase $(\mathbf{b})$, S-phase (c) and $\mathrm{G}_{2} / \mathrm{M}$-phase (d). The values are the means \pm SEM. ${ }^{*} p<0.05$ vs. WT group; ${ }^{*} p<0.05$ vs. apoE ${ }^{-/-}$group (one-way ANOVA)

excessive ROS lead to double-strand DNA breaks [7, 8]. The micronucleus test is a simple and quick technique commonly used for the detection of genotoxicity and cytotoxicity induced by chemical substances [24]. However, in the present study, we used the micronucleus test to investigate the mutagenic effects of hypercholesterolemia in bone marrow cells from atherosclerotic mice. The micronuclei are formed during anaphase due to a mismatch repair of double-strand breaks, which is the most common form of oxidative damage to DNA $[25,26]$. We demonstrate a concurrent increase in ROS production and in MNPCE frequency in apoE ${ }^{-/-}$mice compared with WT animals. Taken together, these data suggest that atherosclerosis is potentially genotoxic. On the other hand, the animals chronically treated with sildenafil exhibit MNPCE close to control levels, suggesting that sildenafil could be an anti-mutagenic drug due to its antioxidative activity. In addition, apoE $\mathrm{E}^{-/-}$ mice showed higher cytotoxicity, evaluated by the ratio of PCE/NCE, compared with WT mice, suggesting that hypercholesterolemia presents cytotoxic action in bone marrow

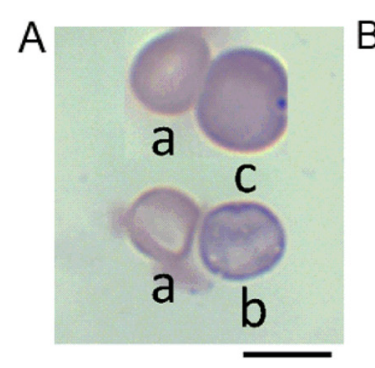

\begin{tabular}{llclc}
\hline \multirow{2}{*}{ Groups } & \multicolumn{2}{c}{ MNPCE/2000 PCE } & & PCE/NCE \\
\cline { 2 - 3 } & Mean \pm SEM & $\%$ & & Mean \pm SEM \\
\hline WT & $3.5 \pm 0.2$ & 0.17 & & $0.5 \pm 0.01$ \\
\hline apoE ${ }^{-/}$ & $6.4 \pm 0.4^{*}$ & 0.32 & & $0.3 \pm 0.03^{*}$ \\
\hline Sildenafil & $5.0 \pm 0.4^{\#}$ & 0.25 & & $0.4 \pm 0.02^{\#}$ \\
\hline
\end{tabular}

Fig. 4 Evaluation of cytotoxicity and genotoxicity. a Typical photomicrographs of polychromatic (a; PCE) and normochromatic (b; NCE) erythrocytes, and micronucleated PCE (c; MNPCE) in bone marrow. $\mathbf{b}$ Table showing the effects of sildenafil treatment on the bone marrow of $\mathrm{apoE}^{-/-}$mice based on MNPCE and PCE/NCE frequency. The values are the means \pm SEM ( $n=7$ per group). ${ }^{*} p<0.05 \mathrm{vs}$. WT. ${ }^{\#} p<0.05 \mathrm{vs}$. apoE ${ }^{-/-}$ (one-way ANOVA). Scale bar: $10 \mu \mathrm{m}$ 
cells of atherosclerotic mice and sildenafil treatment completely abolishes this toxicity. The results of the micronucleus test suggest that chronic administration of sildenafil has anti-genotoxic, anti-cytotoxic and, consequently, antimutagenic effects due to its antioxidant activity in the bone marrow cells of atherosclerotic mice.

It is well known that elevated ROS levels alter cell cycle progression [27-32]. In the present study, we have found that oxidative stress change cell cycling in the bone marrow cells of atherosclerotic mice, as the bone marrow cells in $\mathrm{apoE}^{-/-}$mice were less proliferative than in WT mice (more cells in $G_{0} / G_{1}$ phase, and less in $S$ phase), suggesting that hypercholesterolemia induces a $G_{0} / G_{1}$ arrest in bone marrow cells. In addition, the percentage of bone marrow cells in $\mathrm{S}$ phase decreased in $\mathrm{apoE}^{-/-}$mice and this was accompanied by a simultaneous increase in percentage of cells in $G_{0} / G_{1}$ phase, suggesting an inhibition in the progression of $\mathrm{G} 1$ to $\mathrm{S}$ phase.

The cells arrested in $G_{0} / G_{1}$ phase may die or they may be repaired and re-enter into the next phase of the cell cycle [33-36]. We observed more cells in the sub- $\mathrm{G}_{0}$ phase, due to DNA fragmentation, suggesting an increase in apoptosis in atherosclerotic mice [7, 8]. Interestingly, sildenafil treatment rescued cells from $G_{0} / G_{1}$ growth arrest and decreased DNA fragmentation [7], restoring the normal cell cycle distribution and protecting cells from undergoing apoptosis. Mammalian cells are subject to cycle checkpoints that allow DNA damage repair by slowing or arresting cell cycle progression, thereby preventing the transmission of damaged chromosomes [36-38]. We therefore suspect that the $G_{0} / G_{1}$ arrest observed in our apoE $^{-1-}$ mice may be triggered by oxidative-DNA damage, which was prevented by sildenafil treatment.

To our knowledge, we are the first to use flow cytometry to show that chronic sildenafil treatment by oral gavage, in addition to its vasoactivity, indirectly prevents damage to bone marrow cells by reducing ROS production and genomic instability which, consequently, preserves cell cycle kinetics in different cell types from atherosclerotic and hypertensive mice [7, 10, 12-14]. Considering that the bone marrow is the primary stem cell source in adults and that autologous transplantation is the preferred therapy in clinical applications, our data provide insights into therapeutic potential of bone marrow stem cells from patients with cardiovascular disease.

\section{Conclusions}

In conclusion, our data reveal that the excessive production of ROS in atherosclerotic mice overcome the DNA repair pathways in bone marrow cells. The novelty of the present study is that the administration of sildenafil reduced ROS to baseline levels and, consequently, reverted the DNA damage and its outcomes in bone marrow cells. Of note, there is a lot of efforts to discover a promising pharmacologic strategy to avoid tissue damage induced by oxidative stress. Therefore, further studies are needed to clear the mechanisms by which sildenafil acts as an antioxidant and anti-genotoxic drug.

\section{Acknowledgements}

SSM, BPC and ECV are supported by the National Council for the Development of Science and Technology (CNPq, Ref. 307584/2015-1, 445736/2014-3, 303001/2015-1 \& 476525/2012-8 Grants, respectively) and the State Agency for the Development of Science and Technology (FAPES/

CNPq/PRONEX Grant Ref. 012/2009 and Grant Ref. 2014-Universal 67597483).

\section{Authors' contributions}

FPB and ATB carried out the experimental analysis, acquisition of data, analysis and interpretation of the data and drafted the manuscript. MLP participated in the data acquisition, analysis and interpretation. ECV, BPC and SSM contributed to the conception, design and supervision of the study, interpretation of data and the critical revision of the manuscript. All authors read and approved the final version of the manuscript

\section{Competing interests}

The authors declare that they have no competing interests.

\section{Author details}

${ }^{1}$ Laboratory of Translational Physiology, Health Sciences Center, Federal University of Espirito Santo, Vitoria, Brazil. ${ }^{2}$ Federal Institute of Education, Science and Technology (IFES), Vila Velha, ES, Brazil. ${ }^{3}$ Pharmaceutical Sciences Graduate Program, Vila Velha University (UW), Vila Velha, ES, Brazil.

Received: 26 April 2016 Accepted: 20 May 2016

Published online: 27 May 2016

\section{References}

1. Vasquez EC, Peotta VA, Gava AL, Pereira TM, Meyrelles SS. Cardiac and vascular phenotypes in the apolipoprotein E-deficient mouse. J Biomed Sci. 2012. doi:10.1186/1423-0127-19-22.

2. Vasquez EC, Peotta VA, Meyrelles SS. Cardiovascular autonomic imbalance and baroreflex dysfunction in the apolipoprotein E-deficient mouse. Cell Physiol Biochem. 2012. doi:10.1159/000277623.

3. Meyrelles SS, Peotta VA, Pereira TM, Vasquez EC. Endothelial dysfunction in the apolipoprotein E-deficient mouse: insights into the influence of diet, gender and aging. Lipids Health Dis. 2011. doi:10.1186/1476-511X-10-211.

4. Matthews AT, Ross MK. Oxyradical stress, endocannabinoids, and atherosclerosis. Toxics. 2015. doi:10.3390/toxics3040481.

5. He C, Medley SC, Hu T, Hinsdale ME, Lupu F, Virmani R, Olson LE. PDGFRß signalling regulates local inflammation and synergizes with hypercholesterolaemia to promote atherosclerosis. Nat Commun. 2015. doi:10.1038/ncomms8770.

6. Balarini CM, Leal MA, Gomes IB, Pereira TM, Gava AL, Meyrelles SS, Vasquez EC. Sildenafil restores endothelial function in the apolipoprotein E knockout mouse. J Transl Med. 2013. doi:10.1186/1479-5876-11-3.

7. Rodrigues BP, Campagnaro BP, Balarini CM, Pereira TM, Meyrelles SS, Vasquez EC. Sildenafil ameliorates biomarkers of genotoxicity in an experimental model of spontaneous atherosclerosis. Lipids Health Dis. 2013. doi:10.1186/1476-511X-12-128.

8. Tonini CL, Campagnaro BP, Louro LP, Pereira TM, Vasquez EC, Meyrelles SS. Effects of aging and hypercholesterolemia on oxidative stress and DNA damage in bone Marrow mononuclear cells in apolipoprotein E-deficient mice. Int J Mol Sci. 2013. doi:10.3390/ijms14023325.

9. Gomes IB, Porto ML, Santos MC, Campagnaro BP, Gava AL, Meyrelles SS, Pereira TM, Vasquez EC. The protective effects of oral low-dose quercetin on diabetic nephropathy in hypercholesterolemic mice. Front Physiol. 2015. doi:10.3389/fphys.2015.00247.

10. Leal MA, Balarini CM, Dias AT, Porto ML, Gava AL, Pereira TM, Meyrelles SS, Vasquez EC. Mechanisms of enhanced vasoconstriction in the mouse model of atherosclerosis: the beneficial effects of sildenafil. Curr Pharm Biotechnol. 2015. doi:10.2174/138920101606150407113458.

11. Vasquez EC, Gava AL, Graceli JB, Balarini CM, Campagnaro BP, de Melo C Pereira T, Meyrelles SS. Novel Therapeutic Targets for Phosphodiesterase 5 Inhibitors: current state-of-the-art on systemic arterial hypertension and 
atherosclerosis. Curr Pharm Biotechnol. 2016. doi:10.2174/ 1389201017666151223123904

12. Dias AT, Rodrigues BP, Porto ML, Gava AL, Balarini CM, Freitas FP, Palomino Z, Casarini DE, Campagnaro BP, Pereira TM, Meyrelles SS, Vasquez EC. Sildenafil ameliorates oxidative stress and DNA damage in the stenotic kidneys in mice with renovascular hypertension. J Transl Med. 2014. doi:10. 1186/1479-5876-12-35

13. Dias AT, Cintra AS, Frossard JC, Palomino Z, Casarini DE, Gomes IB, Balarini CM, Gava AL, Campagnaro BP, Pereira TM, Meyrelles SS, Vasquez EC. Inhibition of phosphodiesterase 5 restores endothelial function in renovascular hypertension. J Transl Med. 2014. doi:10.1186/s12967-014-0250-x.

14. Fahning BM, Dias AT, Oliveira JP, Gava AL, Porto ML, Gomes IB, Nogueira BV Campagnaro BP, Pereira TM, Vasquez EC, Balarini CM, Meyrelles SS. Sildenafil improves vascular endothelial structure and function in renovascular hypertension. Curr Pharm Biotechnol. 2015. doi:10.2174/ 1389201016666150610161330.

15. Campagnaro BP, Tonini CL, Doche LM, Nogueira BV, Vasquez EC, Meyrelles SS. Renovascular hypertension leads to DNA damage and apoptosis in bone marrow cells. DNA Cell Biol. 2013. doi:10.1089/dna.2013.2065.

16. Campagnaro BP, Tonini CL, Nogueira BV, Casarini DE, Vasquez EC, Meyrelles SS. DNA damage and augmented oxidative stress in bone marrow mononuclear cells from Angiotensin-dependent hypertensive mice. Int J Hypertens. 2013. doi:10.1155/2013/305202.

17. von Ledebur M, Schmid W. The micronucleus test. Methodological aspects. Mutat Res. 1973. doi:10.1016/0027-5107(73)90118-8.

18. Silva CR, Borges FF, Bernardes A, Perez CN, Silva DM, Chen-Chen L. Genotoxic, cytotoxic, antigenotoxic, and anticytotoxic effects of sulfonamide chalcone using the Ames test and the mouse bone marrow micronucleus test. PLoS One. 2015;10(9):e0137063

19. He F, Zuo L. Redox roles of reactive oxygen species in cardiovascular diseases. Int J Mol Sci. 2015. doi:10.3390/ijms161126059.

20. Konior A, Schramm A, Czesnikiewicz-Guzik M, Guzik TJ. NADPH oxidases in vascular pathology. Antioxid Redox Signal. 2014. doi:10.1089/ars.2013.5607.

21. Li H, Horke S, Förstermann U. Vascular oxidative stress, nitric oxide and atherosclerosis. Atherosclerosis. 2014. doi:10.1016/j.atherosclerosis.2014.09.001.

22. Goncharov NV, Avdonin PV, Nadeev AD, Zharkikh IL, Jenkins RO. Reactive oxygen species in pathogenesis of atherosclerosis. Curr Pharm Des. 2015. doi:10.2174/1381612820666141014142557.

23. Porto ML, Rodrigues BP, Menezes TN, Ceschim SL, Casarini DE, Gava AL, Pereira TM, Vasquez EC, Campagnaro BP, Meyrelles SS. Reactive oxygen species contribute to dysfunction of bone marrow hematopoietic stem cells in aged C57BL/6J mice. J Biomed Sci. 2015. doi:10.1186/s12929-015-0201-8.

24. Schmid W. The micronucleus test. Mutat Res. 1975. doi:10.1016/01651161(75)90058-8.

25. Fenech M, Kirsch-Volders M, Natarajan AT, Surralles J, Crott JW, Parry J, Norppa H, Eastmond DA, Tucker JD, Thomas P. Molecular mechanisms of micronucleus, nucleoplasmic bridge and nuclear bud formation in mammalian and human cells. Mutagenesis. 2011;26(1):125-32. PubMed PIMD: 21164193.

26. Kirsch-Volders M, Decordier I, Elhajouji A, Plas G, Aardema MJ, Fenech M. In vitro genotoxicity testing using the micronucleus assay in cell lines, human lymphocytes and 3D human skin models. Mutagenesis. 2011. doi:10.1093/ mutage/geq068.

27. Clopton DA, Saltman P. Low-level oxidative stress causes cell-cycle specific arrest in cultured cells. Biochem Biophys Res Commun. 1995. doi:10.1006/ bbrc.1995.1645.

28. Barzilai A, Yamamoto K. DNA damage responses to oxidative stress. DNA Repair. 2004. doi:10.1016/j.dnarep.2004.03.002.

29. Chang MC, Lin LD, Wu MT, Chan CP, Chang HH, Lee MS, Sun TY, Jeng PY, Yeung SY, Lin HJ, Jeng JH. Effects of camphorquinone on cytotoxicity, cell cycle regulation and prostaglandin E2 production of dental pulp cells: role of ROS, ATM/Chk2, MEK/ERK and hemeoxygenase-1. PLoS One. 2015;10(12):e0143663.

30. Chang MY, Shieh DE, Chen CC, Yeh CS, Dong HP. Linalool induces cell cycle arrest and apoptosis in leukemia cells and cervical cancer cells through CDKls. Int J Mol Sci. 2015. doi:10.3390/ijms161226089.

31. Samikkannu T, Ranjith D, Rao KV, Atluri VS, Pimentel E, El-Hage N, Nair MP. HIV-1 gp120 and morphine induced oxidative stress: role in cell cycle regulation. Front Microbiol. 2015. doi:10.3389/fmicb.2015.00614.

32. Yuan $X$, Shan $Y$, Zhao Z, Chen J, Cong Y. G0/G1 arrest and apoptosis induced by SARS-CoV 3b protein in transfected cells. Virol J. 2005. doi:10. 1186/1743-422X-2-66.
33. Yoo KD, Park ES, Lim Y, Kang SI, Yoo SH, Won HH, Kim YH, Yoo ID, Yoo HS, Hong JT, Yun YP. Clitocybin A, a novel isoindolinone, from the mushroom Clitocybe aurantiaca, inhibits cell proliferation through G1 phase arrest by regulating the PI3K/Akt cascade in vascular smooth muscle cells. J Pharmacol Sci. 2012. doi:10.1254/jphs.11159FP.

34. Yang M, Zhong J, Zhao M, Wang J, Gu Y, Yuan X, Sang J, Huang C. Overexpression of nuclear apoptosis-inducing factor 1 altered the proteomic profile of human gastric cancer cell MKN45 and induced cell cycle arrest at G1/S phase. PLoS One. 2014;9(6):e100216.

35. Yuan L, Zhang Y, Xia J, Liu B, Zhang Q, Liu J, Luo L, Peng Z, Song Z, Zhu R. Resveratrol induces cell cycle arrest via a p53-independent pathway in A549 cells. Mol Med Rep. 2015. doi:10.3892/mmr.2014.3100.

36. Chang MC, Chang HH, Chan CP, Yeung SY, Hsien HC, Lin BR, Yeh CY, Tseng WY, Tseng SK, Jeng JH. p-Cresol affects reactive oxygen species generation, cell cycle arrest, cytotoxicity and inflammation/atherosclerosis-related modulators production in endothelial cells and mononuclear cells. PLoS One. 2014;9(12): e114446.

37. Ahamad MS, Siddiqui S, Jafri A, Ahmad S, Afzal M, Arshad M. Induction of apoptosis and antiproliferative activity of naringenin in human epidermoid carcinoma cell through ROS generation and cell cycle arrest. PLOS One. 2014. doi:10.1371/journal.pone.0110003.

38. Cataldi A, Zara S, Rapino M, Zingariello M, di Giacomo V, Antonucci A. p53 and telomerase control rat myocardial tissue response to hypoxia and ageing. Eur J Histochem. 2009. doi:10.4081/ejh.2009.e25.

\section{Submit your next manuscript to BioMed Central and we will help you at every step:}

- We accept pre-submission inquiries

- Our selector tool helps you to find the most relevant journal

- We provide round the clock customer support

- Convenient online submission

- Thorough peer review

- Inclusion in PubMed and all major indexing services

- Maximum visibility for your research

Submit your manuscript at www.biomedcentral.com/submit
BioMed Central 